\title{
Biomass Production of Monocultures and Mixtures of Cup Plant and Native Grasses on Prime and Marginal Cropland
}

\author{
Arvid Boe ${ }^{1 *}$, Kenneth A. Albrecht ${ }^{2}$, Paul J. Johnson ${ }^{1,3}$, Jixiang Wu ${ }^{1}$ \\ ${ }^{1}$ Department of Agronomy, Horticulture, and Plant Science, South Dakota State University, Brookings, SD, USA \\ ${ }^{2}$ Department of Agronomy, University of Wisconsin, Madison, WI, USA \\ ${ }^{3}$ Insect Biodiversity Laboratory, South Dakota State University, Brookings, SD, USA \\ Email: *arvid.boe@sdstate.edu, kaalbrecht@wisc.edu,paul.johnson@sdstate.edu, jixiang.wu@sdstate.edu
}

How to cite this paper: Boe, A., Albrecht, K.A., Johnson, P.J. and Wu, J.X. (2019) Biomass Production of Monocultures and Mixtures of Cup Plant and Native Grasses on Prime and Marginal Cropland. American Journal of Plant Sciences, 10, 911-924. https://doi.org/10.4236/ajps.2019.106066

Received: April 24, 2019

Accepted: June 15, 2019

Published: June 18, 2019

Copyright $\odot 2019$ by author(s) and Scientific Research Publishing Inc. This work is licensed under the Creative Commons Attribution International License (CC BY 4.0).

http://creativecommons.org/licenses/by/4.0/

(c) (i) Open Access

\begin{abstract}
To date, most candidate systems for producing herbaceous cellulosic biomass have been composed of monocultures of perennial or annual grasses. Ecosystem goods and services provided from these biomass feedstock production systems could be increased dramatically with mixing of one or more forb species that would increase biodiversity and provide habitat for pollinators. Cup plant (Silphium perfoliatum L.) is featured with many desirable characteristics, such as high biomass potential, adaptation to marginal soils, and attractiveness to pollinators, desirable in a dicot species to grow in mixtures with perennial warm-season grasses. The objective of this study was to compare cup plant, switchgrass (Panicum virgatum L.), and prairie cordgrass (Spartina pectinata Link) monocultures to their mixtures for biomass production on prime and poorly drained marginal crop land for two years in both South Dakota and Wisconsin. In Wisconsin, monocultures of prairie cordgrass and cup plant and their mixture produced more biomass (8.1 $\mathrm{Mg} \mathrm{ha}^{-1}$ ) than the switchgrass monoculture and switchgrass/cup plant mixture (5.3 Mg.ha ${ }^{-1}$ ) on both prime and marginal land. While in South Dakota, drought and meristem destruction by the cup plant moth (Eucosma giganteana Riley) caused large reductions in biomass production $\left(1.7 \mathrm{Mg} \cdot \mathrm{ha}^{-1}\right)$ in both years, with the switchgrass/cup plant mixture on marginal land having the highest yield $\left(2.1 \mathrm{Mg} \cdot \mathrm{ha}^{-1}\right)$. Our study showed binary mixtures of cup plant and native warm-season grasses have great potential for increasing biodiversity and other ecosystem goods and services, relative to monocultures, for sustainable biomass feedstock production on poorly drained marginal land in the northcentral USA.
\end{abstract}




\section{Keywords}

Silphium perfoliatum L., Switchgrass, Panicum virgatum L., Prairie Cordgrass, Spartina pectinata Link, Bioenergy, Pollinators, Eucosma giganteana Riley, Ecosystem Goods and Services

\section{Introduction}

There is a wide area of poorly drained marginal croplands in the northern Great Plains. Because high soil moisture delays or prohibits planting in the spring, most of these marginal lands are economically unprofitable. Enhancing the utilization of these marginal lands through growing adapted perennial plants will greatly benefit farmers economically and provide environmental benefits, as well. Dedicated herbaceous perennial biomass production systems on marginal cropland may increase yield, reduce inputs, and provide increased ecological goods and services over monocultures or mixtures of perennial grasses, if forbs are included in a mixture [1]. Species of Silphium are receiving recent global attention for new multi-purpose crops, including forage [2] [3], biomass [4], remediation, and pollinator-attracting functions [5].

Cup plant (Silphium perfoliatum L.), a perennial species native to North America, has great potential for bioenergy production and enhancement of ecological goods and services. Cup plant's importance has been recently recognized in North America [4] [5], Europe [6] [7] [8], South America, and Asia. A recent study showed cup plant had desirable levels of genetic variation among 33 half-sib families for improving biomass and related morphological traits [4]. An important feature of this species is its adaptation to wet marginal croplands. Its favored natural habitats include moist prairies, meadows near rivers, lake borders, and ditches [9]. In the Dakotas, cup plant occurs only rarely along the eastern edges on alluvial soils [10]; whereas, in Wisconsin it occurs statewide, but is most common in the southern and western regions [11].

Switchgrass (Panicum virgatum L.) monocultures are a leading feedstock choice for producing cellulosic biofuels. However, in natural grasslands, switchgrass is only dominant in a narrow ecological niche of the tall grass prairie. On the other hand, prairie cordgrass (Spartina pectinata Link), which is a tall (1.5 to $2 \mathrm{~m}$ ), robust, native grass with strong rhizomes that can spread 1 - 3 m per year and separate it from the other desirable native warm season grasses, grows throughout the Northeast, Great Lakes and Midwest states as well as most other states in the USA. Prairie cordgrass is commonly found on low, poorly drained soils along roadsides, railroad embankments, ditches, streams, marshes and potholes. It also grows well on seasonally dry sites, and tolerates alkaline soil conditions [12]. Growing binary mixtures of perennial warm-season grasses and legumes has been shown to improve forage production and quality [13]. A recent study demonstrated that monocultures or binary mixtures of native plant species 
with switchgrass, when appropriately matched to their natural landscape positions, produced biomass in equal or greater amounts than switchgrass monocultures [1].

Mixtures of cup plant with native grasses may offer the potential to restore and utilize marginal lands to enhance ecological and economic value [8]; however, it is unknown regarding their responses to different land types under different environments. Therefore, the objectives of this study were: 1) compare switchgrass, prairie cordgrass, and cup plant monocultures to the two individual grass/cup plant binary mixtures and the three-species mixture for biomass production, and 2) determine the contribution of cup plant to biomass in mixtures on prime and poorly drained marginal cropland in eastern South Dakota and southern Wisconsin.

\section{Materials and Methods}

Three native perennial biomass candidate species: switchgrass, prairie cordgrass, and cup plant, were used for this study. Seeds of "Summer" switchgrass, a selection of prairie cordgrass from a natural population in eastern South Dakota [14], and a selection of cup plant derived from natural populations in Illinois and Minnesota [4] were planted in the greenhouse in cone-tainers (Stuewe and Sons Inc., Tangent, OR) during February 2010 to provide equal-condition seedlings transplanted to the field in May 2011.

Transplanted nurseries of monocultures (Figure 1(a) and Figure 1(b)), binary grass/cup plant mixtures (Figure $1(\mathrm{c})$ ), and the tertiary mixture of switchgrass, prairie cordgrass, and cup plant were established at Brookings, SD and Arlington, WI in June 2011. Experimental units were composed of 24 transplants arranged in three rows of eight plants with $0.92-\mathrm{m}$ inter-row spacing and $0.35-\mathrm{m}$ intra-row spacing. For the two grass/cup plant binary mixtures, four plants of each species were alternately planted in each of the three rows (Figure 1(c)). For the tertiary mixture, three plants for two species and two plants for the third were randomly planted within each of the three rows. A randomized complete block design with three replications of each of the three monocultures, two binary mixtures, and one tertiary mixture was applied at each of two sites within marginal and prime cropland areas at both locations. However, only one site at Brookings was established within the marginal cropland area.

Soil types at Brookings were a Brandt silty clay loam (fine-silty, mixed, superactive, frigid Calcic Hapludolls) on prime land $\left(44.3052^{\circ} \mathrm{N}, 96.6693^{\circ} \mathrm{W}\right)$ and a McKranz (fine-silty, mixed, superactive, frigid Aeric Calciaquolls)-Badger silty clay loam (fine, smectitic, frigid Vertic Ariaquolls) on marginal land $\left(44.3689^{\circ} \mathrm{N}\right.$, $\left.96.7945^{\circ} \mathrm{W}\right)$. At Arlington $\left(44.3052^{\circ} \mathrm{N}, 89.3725^{\circ} \mathrm{W}\right.$ ) Warsaw loam (fine-loamy over sandy-skeletal, mixed, superactive, mesic Typic Argiudoll) and Ringwood silt loam (fine-loamy, mixed, mesic Typic Argiudoll) soils represented prime cropland. Huntsville silt loam (fine-silty, mixed, mesic Cumulic Hapludoll) and Troxel silt loam (fine-silty, mixed, superactive, mesic Pachic Argiudolls, in 


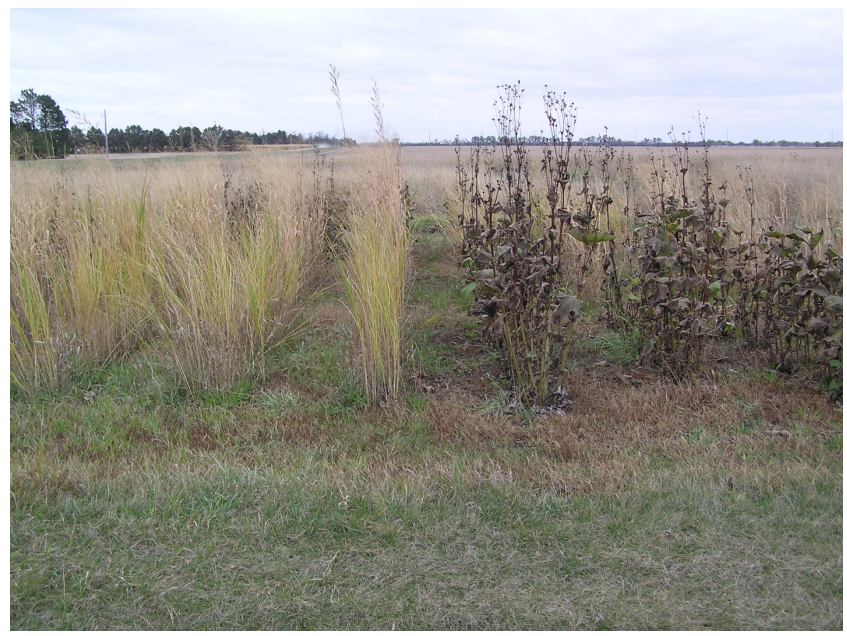

(a)

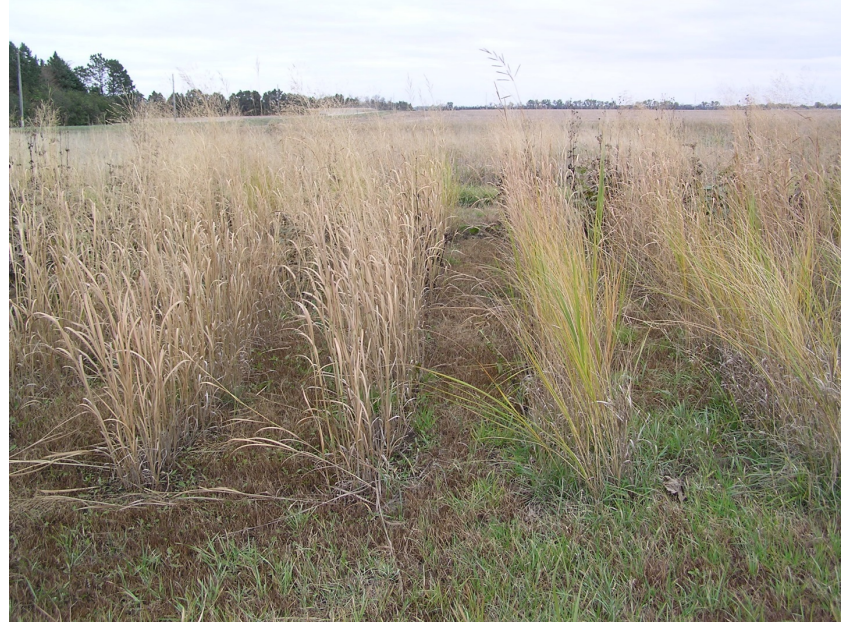

(b)

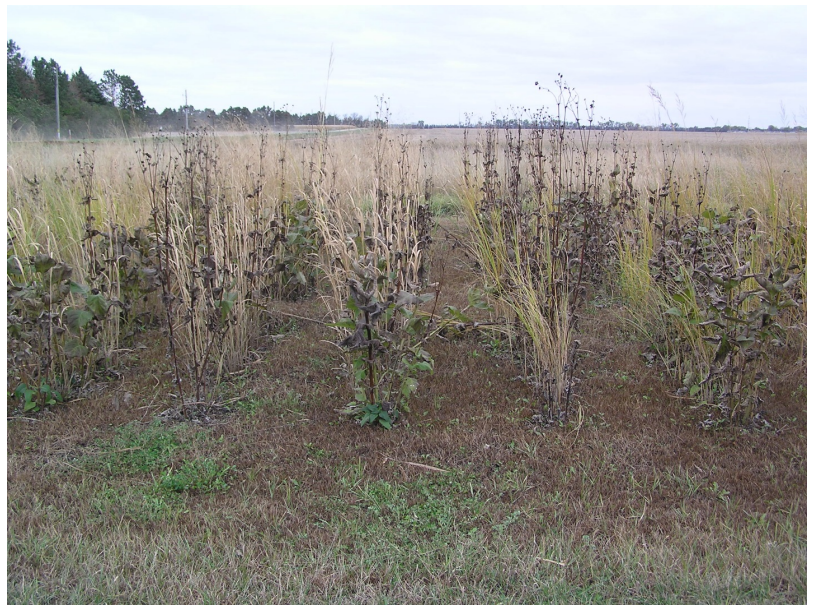

(c)

Figure 1. (a) Monocultures of prairie cordgrass (left 3 rows) and cup plant (right 3 rows); (b) Monocultures of switchgrass (left 2 rows) and prairie cordgrass (right 2 rows); (c) Binary mixtures of cup plant/switchgrass (left 3 rows) and cup plant/prairie cordgrass (right 2 rows). Photos taken on 20 November 2013 at Brookings, SD. Experiments were established from transplanted seedlings in June 2011. 
low-lying areas with a capability class of II because of potential for flood damage from water retention, represented marginal cropland.

At Brookings, no fertilizer was applied during the study. Soil nutrient levels were not determined at planting. The previous crop was soybean [(Glycine max L. Merr.)] for both prime and marginal land components. Therefore, we assumed that about $45 \mathrm{~kg} \mathrm{~N} \mathrm{ha}^{-1}$ would be available during the growing season of the establishment year (i.e., 2011) [15]. Historically, the prime land study area was in a long-term maize (Zea mays L.)-soybean rotation; whereas, the marginal land area was in a long-term wheat (Triticum aestivum L.)-soybean rotation, which was subject to frequent modification by wet soil conditions that precluded timely planting of these grain crops in the spring. At Arlington, the previous crop was alfalfa (Medicago sativa L.). Nitrogen fertilizer was applied annually to both prime and marginal land components at $180 \mathrm{~kg} \mathrm{~N} \mathrm{ha}^{-1}$ in the form of ammonium nitrate. Soil $\mathrm{P}$ and $\mathrm{K}$ were maintained at optimum levels for maize silage production, based on University of Wisconsin recommendations [16].

Plots were hand-harvested in entirety during September at Arlington and November at Brookings in each of 2012 and 2013. Fresh weight for each species (i.e., one component weight for monocultures and two or three component weights for mixtures) was recorded in the field. Grab samples were taken for each species in the field and dried at $60^{\circ} \mathrm{C}$ for 72 hours for dry matter concentration for calculation of biomass determination. After harvest in November 2012 and September 2013, the number of shoots of cup plant were counted in each of the cup plant monoculture, binary mixtures, and tertiary mixture plots at each of Brookings and Arlington.

Biomass data were subjected to analysis of variance for each year under each location. For Arlington, land classification (prime or marginal; hereafter referred to as class), sites within class, and treatments (three monocultures, two binary mixtures, and a tertiary mixture) were considered fixed effects. Replications within sites within class were considered random. For Brookings, the prime class contained two sites, whereas the marginal class had only one site. Fisher's least significance difference (LSD) at 0.05 of probability level was used to compare differences among treatments. Data were analyzed using Statistix 9 [17]. Growing season monthly (March through September) total precipitation data for Brookings, SD and Arlington, WI during 2012 and 2013 are presented in Table 1.

\section{Results}

Due to large variation in environmental conditions between Brookings, SD and Arlington, WI, results including analyses of variance and comparisons among treatment means are presented separately for each location.

Biomass Yield at Arlington, WI

All sources of variation, with the exception of replications within sites within classes in 2013, were significant for both years at Arlington (Table 2). In 2012, 
Table 1. Monthly growing season precipitation (cm) during 2012 and 2013 and 30-year averages for Brookings, SD and Arlington, WI.

\begin{tabular}{ccccccccc}
\hline & Mar & Apr & May & Jun & Jul & Aug & Sep & Total \\
\hline & & & \multicolumn{7}{c}{ Brookings } \\
2012 & 1.4 & 6.8 & 17.5 & 4.1 & 3.5 & 6.3 & 1.8 & 41.4 \\
2013 & 2.5 & 6.6 & 7.6 & 15.0 & 9.1 & 3.8 & 5.8 & 50.4 \\
30 -year & 2.9 & 5.3 & 7.4 & 10.9 & 8.4 & 7.9 & 5.3 & 48.1 \\
& & & & \multicolumn{2}{c}{ Arlington } & & & \\
2012 & 6.1 & 7.9 & 7.4 & 0.8 & 10.9 & 7.4 & 2.8 & 43.3 \\
2013 & 5.8 & 13.7 & 15.2 & 19.0 & 7.6 & 4.6 & 7.6 & 73.5 \\
30 -year & 4.8 & 8.9 & 9.4 & 11.9 & 10.7 & 9.9 & 8.9 & 64.5 \\
\hline
\end{tabular}

Table 2. Mean squares for biomass production of cup plant, switchgrass, and prairie cordgrass in monocultures and mixtures on prime and marginal cropland at Arlington, WI during 2012 and 2013.

\begin{tabular}{cccc}
\hline Source & Degrees of freedom & \multicolumn{2}{c}{$\underline{\text { Year }}$} \\
\cline { 3 - 4 } & & 2012 & 2013 \\
\hline Class (C) & 1 & $153.9^{* *}$ & $79.5^{* *}$ \\
Treatment (T) & 5 & $18.0^{* *}$ & $45.5^{* *}$ \\
$\mathrm{C} \times \mathrm{T}$ & 5 & $14.1^{* *}$ & $16.3^{* *}$ \\
Site w/C (S) & 2 & $172.6^{* *}$ & $105.5^{* *}$ \\
$\mathrm{~T} \times \mathrm{S}$ & 10 & $5.9^{* *}$ & $18.5^{* *}$ \\
Replications w/S & 8 & $4.5^{* *}$ & 6.3 \\
Error & 40 & 0.54 & 3.1 \\
\hline
\end{tabular}

**Significant at $\mathrm{P}=0.01$.

grand means were 1.8 times higher $\left(6.3 \mathrm{Mg} \cdot \mathrm{ha}^{-1}\right)$ for the marginal class than for the prime class $\left(3.4 \mathrm{Mg} \cdot \mathrm{ha}^{-1}\right)$. Large differences were also found between sites within classes, with site means of $8.3 \mathrm{Mg} \cdot \mathrm{ha}^{-1}$ and $4.3 \mathrm{Mg} \cdot \mathrm{ha}^{-1}$ on marginal land and site means of $5.8 \mathrm{Mg} \cdot \mathrm{ha}^{-1}$ and $1.0 \mathrm{Mg} \cdot \mathrm{ha}^{-1}$ on prime land (Table 3 ).

Since the class $\times$ treatment mean square was highly significant in each of 2012 and 2013, separate analyses of variance were conducted for each class in each year. Those analyses showed the monoculture of prairie cordgrass produced significantly more biomass than all other treatments on prime land in 2012 (Table 3). Whereas, on marginal land, monocultures of prairie cordgrass and cup plant and their binary mixture produced significantly more biomass than the switchgrass monoculture, the switchgrass/cup plant binary mixture and the tertiary mixture (Table 3). In 2013, the monoculture of prairie cordgrass produced more biomass than the cup plant and switchgrass monocultures and the cup plant/switchgrass mixture on prime land (Table 4). Similarly, on marginal land the prairie cordgrass monoculture produced more biomass than the switchgrass 
Table 3. Mean biomass yields $\left(\mathrm{Mg} \cdot \mathrm{ha}^{-1}\right)$ for monocultures and mixtures of switchgrass, prairie cordgrass, and cup plant on prime and marginal cropland at Arlington, WI during 2012.

\begin{tabular}{ccc}
\hline \multirow{2}{*}{ Treatment } & \multicolumn{2}{c}{ Class } \\
\cline { 2 - 3 } Monocultures & Prime & Marginal \\
Switchgrass (SG) & 3.4 & 2.3 \\
Prairie cordgrass (PC) & 4.4 & 8.4 \\
Cup plant (CP) & 2.9 & 7.7 \\
Binary mixtures & & \\
SG/CP & 2.9 & 5.3 \\
PCG/CP & 3.3 & 7.7 \\
Tertiary mixture & & 6.3 \\
SG/PCG/CP & 3.4 & 2.0 \\
lsd (0.05) & 0.8 & \\
\hline
\end{tabular}

Table 4. Mean biomass yields $\left(\mathrm{Mg} \cdot \mathrm{ha}^{-1}\right)$ for monocultures and mixtures of switchgrass, prairie cordgrass, and cup plant on prime and marginal cropland at Arlington, WI during 2013.

\begin{tabular}{ccc}
\hline Treatment & \multicolumn{2}{c}{ Class } \\
\cline { 2 - 3 } & Prime & Marginal \\
\hline Monocultures & 7.6 & 5.0 \\
Switchgrass (SG) & 10.5 & 13.6 \\
Prairie cordgrass (PC) & 7.4 & 10.8 \\
Cup plant (CP) & & \\
Binary mixtures & 6.5 & 9.7 \\
SG/CP & 8.7 & 11.6 \\
PCG/CP & & 10.8 \\
Tertiary mixture & 8.6 & 3.2 \\
SG/PCG/CP & 2.6 & \\
lsd (0.05) & & \\
\hline
\end{tabular}

monoculture and the switchgrass/cup plant mixture; however, biomass yields of any treatment containing prairie cordgrass, cup plant, or both were comparable (Table 4). The switchgrass monoculture was the only treatment that produced more biomass on prime land than on marginal land (Table 3 and Table 4).

Biomass Yield at Brookings, SD

Significant differences were detected among the three class/site plantings at Brookings, SD in both 2012 and 2013 (Table 5). Mean biomass production was $1.4 \mathrm{Mg} \cdot \mathrm{ha}^{-1}$ for the single site on marginal land, which was similar $\left(1.3 \mathrm{Mg} \cdot \mathrm{ha}^{-1}\right)$ to one of the two sites on prime land, but greater than the other $\left(0.98 \mathrm{Mg}^{-\mathrm{ha}^{-1}}\right)$. 
Table 5. Mean squares for monocultures and mixtures of switchgrass, prairie cordgrass, and cup plant on prime and marginal cropland at Brookings, SD during 2012 and 2013.

\begin{tabular}{cccc}
\hline \multirow{2}{*}{ Source } & Degrees of freedom & \multicolumn{2}{c}{ Year } \\
\cline { 3 - 4 } & 2 & $1.05^{* *}$ & 2013 \\
\hline Class/Site $(\mathrm{CS})$ & 5 & 0.31 & $4.09^{* *}$ \\
Treatment $(\mathrm{T})$ & 10 & 0.32 & $0.72^{\star}$ \\
$\mathrm{CS} \times \mathrm{T}$ & 6 & $0.59^{* *}$ & $0.78^{\star *}$ \\
Rep w/CS & 30 & 0.15 & $0.80^{* *}$ \\
Error & & & 0.23 \\
\hline
\end{tabular}

*, **Significant at $\mathrm{P}=0.05$ and 0.01 , respectively.

In 2013 , the class/site $\times$ treatment mean square was significant, so separate analyses were conducted for the single site on marginal land and for the combined two sites on prime land. Results of those analyses indicated differences among treatments on marginal land (Table 6); whereas, no differences among treatments or between sites were found on prime land. On marginal land at Brookings in 2013, the highest yielding treatments were mixtures, with the switchgrass/cup plant mixture producing significantly more biomass than the switchgrass and prairie cordgrass monocultures (Table 6).

\section{Biomass Contribution by Cup Plant in Mixtures}

Additional analyses were conducted regarding biomass contribution by cup plant in mixtures (i.e., switchgrass/cup plant, prairie cordgrass/cup plant, and switchgrass/prairie cordgrass/cup plant) plots at both Arlington and Brookings (Figure 1) in 2012 and 2013. Analyses of variance for Arlington is presented in Table 7. Significant differences were found between classes and among treatments for the proportion of total biomass contributed by cup plant in mixtures at Arlington in each of 2012 and 2013. However, the class $\times$ treatment mean square was also significant in 2012 (Table 7).

For the 2012 data, separate analyses of variance for each class revealed significant differences among treatments and among sites within classes for cup plant contribution to biomass (Table 8). The contribution from cup plant was similar in the binary mixtures on prime land in 2012; whereas, on marginal land the contribution from cup plant was greater in the switchgrass binary mixture. Similarly, in 2013, the contribution of cup plant averaged across the three mixtures, was 0.61 on prime land and 0.79 on marginal land. Also, the contribution of cup plant was greater in the switchgrass mixture compared with the prairie cordgrass mixture (Table 8).

In South Dakota, no difference was found between years for proportion of total biomass contributed by cup plant. However, highly significant $(\mathrm{P}<0.01)$ differences between sites (i.e., two sites on prime cropland and one site on marginal land) and among treatments main effects were observed. Averaged across the two years, proportion of total biomass contributed by cup plant was 0.61 and 0.43 for the two sites on prime land and 0.51 for the site on marginal land. For 


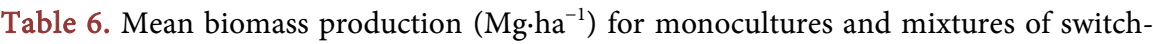
grass, prairie cordgrass, and cup plant on marginal land at Brookings during 2013.

\begin{tabular}{cc}
\hline Treatment & Biomass \\
\hline Monocultures & \\
Switchgrass (SG) & 1.48 \\
Prairie cordgrass (PCG) & 1.41 \\
Cup plant & 1.75 \\
Binary mixtures & \\
SG/CP & 2.1 \\
PCG/CP & 1.77 \\
Tertiary mixture & 1.97 \\
lsd (0.05) & 0.55 \\
\hline
\end{tabular}

Table 7. Mean squares for the contribution of cup plant to biomass in mixtures with native warm-season grasses on prime and marginal cropland at Arlington, WI during 2012 and 2013.

\begin{tabular}{cccc}
\hline & & \multicolumn{2}{c}{ Year } \\
\cline { 3 - 3 } Source & Degrees of freedom & 2012 & 2013 \\
\cline { 3 - 4 } Class $(\mathrm{C})$ & 1 & $0.50^{\star *}$ & $0.30^{\star *}$ \\
Treatment $(\mathrm{T})$ & 2 & $0.19^{\star *}$ & $0.17^{\star *}$ \\
$\mathrm{C} \times \mathrm{T}$ & 2 & $0.066^{\star *}$ & 0.004 \\
Site w/C (S) & 2 & $0.017^{\star *}$ & $0.025^{*}$ \\
$\mathrm{~T} \times \mathrm{S}$ & 4 & 0.006 & 0.014 \\
Replications w/S & 8 & $0.013^{* *}$ & 0.012 \\
Error & 16 & 0.002 & 0.005 \\
\hline
\end{tabular}

*, ** Significant at $\mathrm{P}=0.05$ and 0.01 , respectively.

Table 8. Mean proportion of total biomass contributed by cup plant in mixtures with native warm-season grasses on prime and marginal cropland at Arlington, WI in 2012 and 2013.

\begin{tabular}{cccc}
\hline Mixture & \multicolumn{2}{c}{$\underline{\mathbf{2 0 1 2}}$} & \multirow{2}{2013}{} \\
\cline { 2 - 3 } & Prime & Marginal & \\
\hline Switchgrass/cup plant & 0.47 & 0.88 & 0.84 \\
Prairie cordgrass/cup plant & 0.45 & 0.58 & 0.66 \\
Switchgrass/prairie cordgrass/cup plant & 0.34 & 0.51 & 0.61 \\
lsd (0.05) & 0.06 & 0.08 & 0.06 \\
\hline
\end{tabular}

mixtures, mean proportion of biomass contributed by cup plant was similar for the binary mixtures $(0.58$ for the prairie cordgrass mixture and 0.54 for the switchgrass mixture); the cup plant component of the tertiary mixture was $30 \%$ lower than for the binary mixtures. 
Number of cup plant shoots $\mathrm{m}^{-2}$ varied among treatments at both Brookings in 2012 and Arlington in 2013. The range of the four treatment means at Arlington was from 6.0 to 11.5 shoots $\mathrm{m}^{-2}$ for the tertiary mixture and cup plant monoculture, respectively; whereas, at Brookings the range was from 2.0 to 3.6 for the same treatments, respectively.

\section{Discussion}

Severe drought occurred during the 2012 growing season at Brookings. Precipitation during June through September was $39 \%$ of the 30 -year average (Table 1). In 2013, precipitation during April through July was $80 \%$ of the 30 -year average (Table 1). In addition, a severely limiting biotic factor in both years was heavy infestation of floral meristems of cup plant by the larvae of the cup plant moth. Greater than $90 \%$ of the meristems were destroyed by the larvae in 2012, resulting in reduced phytomer number and no accumulation of biomass beyond mid-July; whereas in 2013, about $50 \%$ of the meristems were destroyed. Consequently, some biomass accumulation occurred through flowering. For cup plant to be a viable biomass crop in the northern Great Plains, in monoculture or mixtures, control of the cup plant moth is paramount [18]. Interestingly, also in 2013 , this same population of cup plant produced $>20 \mathrm{Mg} \cdot \mathrm{ha}^{-1}$ in monoculture and in a binary mixture with prairie cordgrass $35 \mathrm{~km}$ from the experimental sites in the present study [1]. The cup plant moth did not occur at that location. Also, the plant density was four times higher than in the present study.

The biomass production of two-year-old cup plant monocultures $\left(10.8 \mathrm{Mg} \cdot \mathrm{ha}^{-1}\right)$ at Arlington in September 2013 was comparable to that produced from a De-

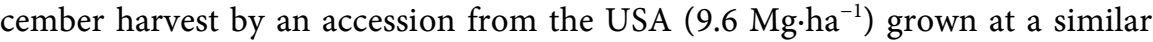
plant density (i.e., 20,000 plants ha ${ }^{-1}$ ) at $51^{\circ} \mathrm{N}$ latitude in Germany [8]. However, in that same study, an accession from Russia produced $\left(14.3 \mathrm{Mg} \cdot \mathrm{ha}^{-1}\right)$. In comparison, in western Lithuania $\left(56^{\circ} \mathrm{N}\right.$ latitude), a cup plant accession (origin not provided) in the same 20,000 plants ha ${ }^{-1}$ density produced $8.5 \mathrm{Mg} \cdot \mathrm{ha}^{-1}[6]$ in the first production year. In the second production year, that accession produced 21.9 Mg.ha ${ }^{-1}$.

In addition to the cup plant moth at Brookings, we also observed biomassreducing morphological damage to switchgrass caused by the switchgrass midge (Chilophaga virgati Gagné) [19] [20] and stunting and discoloration to prairie cordgrass due to phloem-feeding adults and nymphs of Ischnodemus falicus Say [14]. The impact of the switchgrass midge on biomass production is more likely to be evident in spaced-plantings, such as were used in the present study, than in solid stands [19].

The 2012 growing season was also droughty at Arlington, with April through September precipitation 52\% of the 30-year average. However, in 2013 growing-season precipitation was $15 \%$ above average (Table 1). Consequently, the grand biomass mean in 2013, averaged across classes and treatments, was twice that of the 2012 grand biomass mean. 
The competitiveness of cup plant on poorly drained marginal land at Arlington was more obvious in the binary mixture with switchgrass compared with the prairie cordgrass binary mixture. This was not surprising as Weaver [21] considered cup plant to be one of the most adapted forbs in lowlands of the natural tallgrass prairie, where prairie cordgrass is also well-adapted. The fact that the cup plant/prairie cordgrass binary mixture and the tertiary mixture produced amounts of biomass comparable to those of cup plant and prairie cordgrass monocultures on prime and marginal cropland at Arlington was particularly encouraging. Biomass production was not reduced by increasing ecological goods and services, such as pollinator habitat, with a simple forb/grass mixture.

A comprehensive review of biomass data from switchgrass monocultures and switchgrass mixtures, primarily with legumes, concluded that switchgrass monocultures yielded more than switchgrass mixtures, with the exception of legume mixtures which produced similar yields to monocultures [22]. These data were presumably obtained from predominately prime cropland. More recently, Jungers et al. [23] conducted a 7-year study of 12 different native plant mixtures at eight locations in Minnesota and North Dakota and found that, in general switchgrass produced as much or more biomass than monocultures of other grass or grass-forb mixtures. However, without $\mathrm{N}$ fertilizer, an eight-species grass/legume mixture produced as much biomass switchgrass in a single harvest at the end of the growing season system. The biomass yields of the switchgrass monoculture on marginal and prime land in Wisconsin in this study were similar to those reported for fertilized and non-fertilized switchgrass monocultures, respectively, in a long-term study from multiple locations in Minnesota [23].

The phenology of cup plant is somewhat different from that of the two native warm-season grasses in this study. Cup plant usually begins to green up in late March and often suffers frost damage/death to the first few emergent basal leaves prior to internode elongation. On the other hand, prairie cordgrass produces emergent tillers composed of overlapping scale-like bladeless leaves during autumn. The growing points of these tillers are located below ground level until growth resumes in the spring. During spring, elongate bladed leaves begin to emerge during April. These first elongate leaves are occasionally damaged by frost, as well. In contrast, switchgrass tillers normally begin to emerge about two weeks to a month after the onset of leaf elongation of fall-emergent tillers of prairie cordgrass. Although these distinct phenological differences exist between cup plant and the grasses during the early part of the growing season, all three reach peak standing crop at anthesis during early to mid-August.

Superior performance of cup plant and mixtures of cup plant and prairie cordgrass on marginal cropland vs on prime cropland demonstrated an ecological rationale to include this pollinator friendly plant in sustainable cellulosic biomass production systems in mixtures with perennial warm-season grasses. Although the results from Brookings, because of unacceptably low biomass production due to adverse growing conditions, did not clearly identify any of the six plant communities as superior, the fact that the mixtures produced $30 \%$ 
more biomass than the monocultures provided encouragement for additional research.

It should be pointed out that this study of transplants used a single plant population density (i.e., 20,000 plants ha ${ }^{-1}$ ) and a single species ratio in the mixtures (i.e., 1:1 in binary mixtures and 1:1:1 in the tertiary mixture). Little is known about variation in biomass of cup plant in response to variation in plant population density or in response to variation in proportion of each species in a mixture. Mangan et al. [24] planted cup plant at a rate of 25 seeds $\mathrm{m}^{-2}$ in high-diversity native plant polycultures at four locations in Minnesota and North Dakota, but reported no seedling establishment at any of the locations. However, results of our study conducted in South Dakota and Wisconsin suggested that, at the plant population density used in this study, biomass production of mixtures could be expected to reflect the production of the individual components in monocultures across a wide geographic area.

\section{Acknowledgements}

Funding for this research was supported by funding from the North Central Regional Sun Grant Center at South Dakota State University through US Department of Energy Bioenergy Technologies Office under award number DE-FG3608G088073. It was partially supported by USDA-NIFA Hatch Project 1005459.

\section{Conflicts of Interest}

The authors declare no conflicts of interest regarding the publication of this paper.

\section{References}

[1] Zilverberg, C.J., Teoh, K., Boe, A., Johnson, W.C. and Owens, V. (2016) Strategic Use of Native Species on Environmental Gradients Increases Diversity and Biomass Relative to Switchgrass Monocultures. Agriculture, Ecosystems, and Environment, 215, 110-121. https://doi.org/10.1016/j.agee.2015.09.006

[2] Han, K.J., Albrecht, K.A., Mertens, D.R. and Kim, D.A. (2000) Comparison of in Vitro Digestion Kinetics of Cup Plant and Alfalfa. Asian-Australian Journal of Animal Science, 13, 641-644. https://doi.org/10.5713/ajas.2000.641

[3] Han, K.J., Albrecht, K.A., Muck, R.E. and Kim, D.A. (2000) Moisture Effect on Fermentation Characteristics of Cup Plant Silage. Asian-Australian Journal of Animal Science, 13, 636-640. https://doi.org/10.5713/ajas.2000.636

[4] Asseffa, T., Wu, J., Albrecht, K.A., Johnson, P.J. and Boe, A. (2015) Genetic Variation for Biomass and Related Morphological Traits in Cup Plant (Silphium perfoliatum L.). American Journal of Plant Sciences, 6, 1098-1108. https://doi.org/10.4236/ajps.2015.68114

[5] Van Tassel, D.L., Albrecht, K.A., Bever J.D., Boe, A.A., Brandvain, Y., Crews, T.E., Gansberger, M., Gerstberger, P., Gonzalez-Paleo, L., Hulke, B.S., Kane, N.C., Johnson, P.J., Pestsova, E.G., Risso,, V.D.P., Prasifka J.R., Ravetta, D.A., Schlautman, B. Sheaffer, C.C., Smith, K.P., Speranza, P.R., Turner, M.K., Vilela, A.E., von Gehren, P. and Wever, C. (2017) Accelerating Silphium Domestication: An Opportunity to Develop New Crop Ideotypes and Breeding Strategies Informed by Multiple Discip- 
lines. Crop Science, 57, 1274-1284. https://doi.org/10.2135/cropsci2016.10.0834

[6] Šiaudinis, G., Jasinskas, A., Šlepetienè, A. and Karčauskienė, D. (2012) The Evaluation of Biomass and Energy Productivity of Common Mugwort (Artemisia vulgaris L.) and Cup Plant (Silphium perfoliatum L.). Zemdirbyste-Agriculture, 99, 357-362.

[7] Gansberger, M., Montgomery, L.F.R. and Liebhard, P. (2015) Botanical Characteristics, Crop Management and Potential of Silphium perfoliatum L. as a Renewable Resource for Biogas Production: A Review. Industrial Crop Production, 63, 362-372. https://doi.org/10.1016/j.indcrop.2014.09.047

[8] Wever, C., Höller, M., Becker, L., Biertümpfel, A., Köhler, J., van Inghelandt, D., Westhoff, P., Pude, R. and Pestsova, E. (2019) Towards High-Biomass Yielding Bioenergy Crop Silphium perfoliatum L.: Phenotypic and Genotypic Evaluation of Five Cultivated Populations. Biomass and Bioenergy, 124, 102-113.

https://doi.org/10.1016/j.biombioe.2019.03.016

[9] Barkley, T.M. (1986) Asteraceae. In: Great Plains Flora Association, et al., Eds., Flora of the Great Plains, University Press of Kansas, Lawrence.

[10] VanBruggen, T. (1985) The Vascular Plants of South Dakota. 2nd Edition, Iowa State University Press, Ames.

[11] Online Virtual Flora of Wisconsin (2015). http://wisflora.herbarium.wisc.edu/taxa/index.php?taxon=6871

[12] Mobberley, D.G. (1956) Taxonomy and Distribution of the Genus Spartina. Iowa State College Journal of Science, 30, 471-574.

[13] Posler, G.L., Lenssen, A.W. and Fine, G.L. (1993) Forage Yield, Quality, Compability, and Persistence of Warm-Season Grass-Legume Mixtures. Agronomy Journal, 85, 554-560. https://doi.org/10.2134/agronj1993.00021962008500030007x

[14] Boe, A., Johnson, P.J., Owens, V., Lee, D.K., Guo, J. and Gonzalez-Hernandez, J.L. (2017) Genetics and Partitioning for Biomass of Prairie Cordgrass Compared with Switchgrass on Marginal Cropland. Bioenergy Research, 10, 864-875. https://doi.org/10.1007/s12155-017-9849-0

[15] Hoeft, R.G., Nafziger, E.D., Johnson, R.R. and Aldrich, S.R. (2000) Modern Corn and Soybean Production. MCSP Publications, Champaign.

[16] Laboski, C.A.M. and Peters, J.B. (2012) Nutrient Application Guidelines for Field, Vegetable, and Fruit Crops in Wisconsin. University of Wisconsin Extension Bulletin A 2809. University of Wisconsin Cooperative Extension Service, Madison.

[17] Statistix 9 (2008) Analytical Software. Tallahassee.

[18] Johnson, P.J. and Boe, A. (2011) Three Interesting Insects and the Cause of Reduced Vigor of Cup Plant (Silphium perfoliatum) in Agronomic Plantings. Proceedings of the South Dakota Academy of Science, 90, 209.

[19] Boe, A. and Gagné, R.J. (2011) A New Species of Gall Midge (Diptera: Cecidomyiidae) Infesting Switchgrass in the Northern Great Plains. Bioenergy Research, 4, 77-84. https://doi.org/10.1007/s12155-010-9102-6

[20] Calles Torrez, V., Johnson, P.J. and Boe, A. (2014) The Switchgrass Gall Midge (Chilophaga virgati Gagné) in the Northern Great Plains. Bioenergy Research, 7, 417-423. https://doi.org/10.1007/s12155-013-9386-4

[21] Weaver, J.W. (1954) North American Prairie. Johnsen Publishing Co., Lincoln.

[22] Wang, D., Lebauer, D.S. and Dietze, M.C. (2010) A Quantitative Review Comparing the Yield of Switchgrass in Monocultures and Mixtures in Relation to Climate and Management Factors. Global Change Biology Bioenergy, 2, 16-25.

https://doi.org/10.1111/j.1757-1707.2010.01035.x 
[23] Jungers, J.M., Clark, A.T., Betts, K., Mangan, M.E., Sheaffer, C.C. and Wyse, D.L. (2015) Long-Term Biomass Yield and Species Composition in Native Perennial Bioenergy Cropping System. Agronomy Journal, 107, 1627-1640. https://doi.org/10.2134/agronj15.0014

[24] Mangan, M.E., Sheaffer, C., Wyse, D.L., Ehlke, N.J. and Reich, P.B. (2011) Native Perennial Grassland Species for Bioenergy: Establishment and Biomass Productivity. Agronomy Journal, 103, 509-519. https://doi.org/10.2134/agronj2010.0360 